\title{
Pain threshold in adolescents with juvenile idiopathic arthritis and fibromyalgia
}

\author{
Juliana Molina', Liana Sanches ${ }^{2}$, Maria Teresa Terreri', Edson Amaro Jr. ${ }^{2}$, Claudio A. Len ${ }^{1 *}$ \\ From 21st European Pediatric Rheumatology (PReS) Congress \\ Belgrade, Serbia. 17-21 September 2014
}

\section{Introduction}

Pain is a frequent complaint in pediatric practice and is present in several chronic organic diseases, such as juvenile idiopathic arthritis (JIA). While JIA patients show symptoms such as inflammation of the joints and other structures, such as the heart and eyes, patients with idiopathic musculoskeletal pain (IMP) experience a painful condition that is not associated with presence of tissue injuries. Juvenile fibromyalgia (JFM), disorder characterized by recurrence of disabling pain, is a classic example IMP. This study shows preliminary data of a protocol for evaluation of brain activation using functional magnetic resonance imaging (fMRI) after a painful stimulus produced by pressure.

\section{Objectives}

To evaluate and compare the pain threshold in adolescents with JIA and JFM that will be examined by fMRI scan.

\section{Methods}

Twenty nine adolescents were divided into 3 groups: 10 adolescents with JFM, 9 adolescents with JIA and 10 healthy adolescents without complaints of pain.

Using a mechanical system, designed for experiments with fMRI, a series of discrete pressure stimulus were performed, with duration of 5 seconds, applied on the left thumb by a stiff rubber tube connected to a hydraulic piston, enabling a controlled and reproducible stimulation. Participants were asked to graduate the intensity of pain sensation evoked by an ascending series of pressure stimulus, until the subjective rating of pain reported was graded as 4 (four).

\section{Results}

The amount of pressure used in the pressure stimulus was significantly different between groups $(\mathrm{p}=0.0003)$.

${ }^{1}$ Pediatrics, UNIFESP, Brazil

Full list of author information is available at the end of the article
The pain threshold was lower in JFM group (mean pressure used $=3.70 \mathrm{~kg} / \mathrm{cm}^{2}$ ), followed by the group of healthy adolescents $\left(4.45 \mathrm{~kg} / \mathrm{cm}^{2}\right)$ and the JIA group $\left(4.88 \mathrm{~kg} / \mathrm{cm}^{2}\right)$. All participants reported the same subjective pain rating 4 (four).

\section{Conclusion}

Adolescents with JFM presentes a decrease in the threshold for pain, which was significantly lower when compared with adolescents with JIA with long history of organic pain.

\section{Disclosure of interest}

None declared.

\section{Authors' details}

${ }^{1}$ Pediatrics, UNIFESP, Brazil. ${ }^{2}$ Brain Institute, Hospital Albert Einstein, São Paulo, Brazil.

Published: 17 September 2014

\section{doi:10.1186/1546-0096-12-S1-P295}

Cite this article as: Molina et al:: Pain threshold in adolescents with juvenile idiopathic arthritis and fibromyalgia. Pediatric Rheumatology 2014 12(Suppl 1):P295.

Submit your next manuscript to BioMed Central and take full advantage of:

- Convenient online submission

- Thorough peer review

- No space constraints or color figure charges

- Immediate publication on acceptance

- Inclusion in PubMed, CAS, Scopus and Google Scholar

- Research which is freely available for redistribution 